Article

\title{
Super Cooling Point Phenotypes and Cold Resistance in Hyles euphorbiae Hawk Moths from Different Climate Zones
}

\author{
Hana Daneck ${ }^{1}$, Matthias Benjamin Barth ${ }^{1}$, Martin Geck ${ }^{2}$ and Anna K. Hundsdoerfer ${ }^{1, *}$ (D) \\ 1 Museum of Zoology, Senckenberg Natural History Collections Dresden, Königsbrücker Landstrasse 159, \\ D-01109 Dresden, Germany; hana.daneck@senckenberg.de (H.D.); ben.barth@gmx.de (M.B.B.) \\ 2 Säulingstraße 30, D-86163 Augsburg, Germany; m.geck@rocketmail.com \\ * Correspondence: anna.hundsdoerfer@senckenberg.de
}

Citation: Daneck, H.; Barth, M.B.; Geck, M.; Hundsdoerfer, A.K. Super Cooling Point Phenotypes and Cold Resistance in Hyles euphorbiae Hawk Moths from Different Climate Zones. Diversity 2021, 13, 207. https:/ / doi.org/10.3390/d13050207

Academic Editor: Luc Legal

Received: 9 April 2021

Accepted: 8 May 2021

Published: 13 May 2021

Publisher's Note: MDPI stays neutral with regard to jurisdictional claims in published maps and institutional affiliations.

Copyright: (c) 2021 by the authors. Licensee MDPI, Basel, Switzerland. This article is an open access article distributed under the terms and conditions of the Creative Commons Attribution (CC BY) license (https:// creativecommons.org/licenses/by/ $4.0 /)$.

\begin{abstract}
The spurge hawkmoth Hyles euphorbiae L. (Sphingidae) comprises a remarkable species complex with still not fully resolved taxonomy. Its extensive natural distribution range covers diverse climatic zones. This predestinates particular populations to cope with different local seasonally unfavorable environmental conditions. The ability of the pupae to overcome outer frosty conditions is well known. However, the differences between two main ecotypes ('euphorbiae' and 'tithymali') in terms of the inherent degree of frost tolerance, its corresponding survival strategy, and underlying mechanism have not been studied in detail so far. The main aim of our study was to test the phenotypic exhibition of pupae (as the relevant life cycle stadia to outlast unfavorable conditions) in response to combined effects of exogenous stimuli, such as daylight length and cooling regime. Namely, we tested the turnout of subitan (with fast development, unadapted to unfavorable conditions) or diapause (paused development, adapted to unfavorable external influences and increased resistance) pupae under different conditions, as well as their mortality, and we measured the super cooling point (SCP) of whole pupae (in vivo) and pupal hemolymph (in vitro) as phenotypic indicators of cold acclimation. Our results show higher cold sensitivity in 'tithymali' populations, exhibiting rather opportunistic and short-termed cold hardiness, while 'euphorbiae' produces a phenotype of seasonal cold-hardy diapause pupae under a combined effect of short daylight length and continuous cold treatment. Further differences include the variability in duration and mortality of diapause pupae. This suggests different pre-adaptations to seasonal environmental conditions in each ecotype and may indicate a state of incipient speciation within the H. euphorbiae complex.
\end{abstract}

Keywords: Hyles euphorbiae complex; spurge hawkmoth; sphingidae; invertebrate physiology; insect cold tolerance; cold acclimation; supercooling; ecotype; pupa phenotype; functional adaptation; molecular ecology

\section{Introduction}

The natural distribution range of the spurge hawkmoth Hyles euphorbiae Linnaeus covers large parts of the Palearctic region in Europe, Asia, and North Africa, involving diverse climate and vegetation zones. Although extensive genetic and whole genome studies show that all populations of $H$. euphorbiae constitute one genetic entity [1,2], previous investigations focused on morphological as well as genetic variability [3-7] revealed a correlation between the distribution of larval and adult morphotypes, mitochondrial DNA (mtDNA) lineages, and the geographical occurrence of the populations. Moreover, based on mtDNA and nuclear DNA, Mende et al. [1] found two main genetic lineages with geographical correlation, suggesting environmental and climatic barriers as main factors influencing their distribution and the location of the contact zone between them. The lineage 'euphorbiae' (according to Hundsdoerfer, Lee et al. [2]) is distributed in the area of Central, Western, and Eastern Europe with seasonal frosty climatic conditions, while 'tithymali' is prevalent across regions without pronounced cold seasons in Southern Europe 
and Northwestern Africa. Diverse environmental adaptations must not necessarily lead to obvious morphological differences during all life cycle stages, even though two main larval patterns have been observed [6]. A subdivision of the species into geographically delimited entities with ecologically distinct preferences appears to be common in Lepidoptera [8] (reviewed in Aardema et al. [9]), and a correlation with the occurrence of mitochondrial lineages [1,5] could indicate an incipient stage of speciation [1].

Recent gene and protein expression studies notably suggest distinct physiologically adapted 'euphorbiae' pupal phenotypes [10,11]. Especially the pupal stages, although morphologically uniform, are predestined for the study of physiological plasticity, because of their presumed variability in the ability to overcome periods of various unfavorable environmental conditions [5]. Depending on local seasonal weather patterns, populations can establish one or more generations per year. The final larval stage before pupation (fifth instar) shows a high sensitivity to differences in photoperiod and temperature, which are the main factors determining the kind of the pupa stage [12]. The pupae of the 'tithymali' populations from the most southwestern localities in the subtropical climatic zone (e.g., Macaronesia), where the daylight length varies only slightly and the coldest winter temperatures do not fall below an average of $10{ }^{\circ} \mathrm{C}$ [13], are not confronted with distinctive seasonal climatic fluctuations during the year. Although the appearance of all developmental stages throughout the whole year is documented, the most abundant occurrence of adult individuals comprises more or less the winter months (e.g., predominantly SeptemberApril on Canary Islands or February-October on Cape Verde). This timing corresponds to seasonal availability of leaves on larval food plant (Euphorbia). In the summertime, the leaves drop off, the food is scarce, and the majority of larvae do not survive (own observations MG, [14]).

In 'euphorbiae' populations adapted to four seasons (e.g., in temperate Central Europe), the presence of frost-sensitive developmental stages is clearly delimited to the warmer part of the year due to the regular advent of subzero temperatures. During the favorable vegetation period characterized by the 'long day' conditions (up to over 16 light hours per day) together with warm outdoor temperatures, metamorphosis proceeds in quick-hatching (subitan) pupae. This pupal stage develops within only about 2-5 weeks, omitting the stage with externally induced developmental delay - the diapause [14-16]. During the annual advent of inconvenient environmental conditions, the day length shortens (to slightly less than 8 light hours per day). Simultaneously, the temperature decreases successively, reaching its minimum markedly below $0{ }^{\circ} \mathrm{C}$ in winter months [13]. These two external changes initiate cold hardening and trigger diapause of the pupae, the overwintering stage, which may insist up to 2 years [11,17] (own observation). Furthermore, the remarkable temperature and daylight length variation not only influence but also synchronize the annual population cycle [12].

Diapause in insects is a complex process [11,18-21], which is characterized by modifications in the metabolism. The resulting pupa phenotype is manifested by its increased capability to survive ambient conditions [10,11,21].

Focusing on diapause induced by decreasing external temperatures in freeze avoiding insects, which do not tolerate the formation of internal ice inside of their bodies [22], the ability to supercool their body fluids is crucial to cope with subzero temperatures $[18,23]$. This means, they are able to depress the temperature, at which freezing is initiated spontaneously, below the melting point of water, without changing the phase due to the lack of nucleation sources [18]. Cryoprotectants such as polyols (e.g., glycerol), sugars (glucose, trehalose), and proteins (e.g., antifreeze proteins) facilitate supercooling in the organism and prevent freezing damage [24]. The supercooling point (SCP) is the temperature at which spontaneous crystallization cannot be further suppressed. Freeze-avoidant insects are not able to survive SCP temperatures or below [25]. The physiological phenotype of the pupae is thus expected to be indirectly detectable by calorimetric measurements of the SCP. This in combination with the direct experimental detection of the survival ability (mortality) of individuals at various ambient temperatures may discern overwintering 
diapause stages from subitan pupae, as well as differentially cold-hardy phenotypes of distinct $H$. euphorbiae populations.

That diapause pupae of 'euphorbiae' populations survive subzero temperatures is well known. In contrast, no cold-induced diapause as well as no ability of pupae to survive at lower temperatures (under $7^{\circ} \mathrm{C}$ ) was observed in eremial North African 'tithymali' populations [14,26] (and own observations MG). For 'euphorbiae', Harbich (pers. comm.) reported that gradual cooling to $4{ }^{\circ} \mathrm{C}$ under laboratory conditions allowed overwintering of diapause pupae under subzero temperatures. Precooled pupae were able to reach stronger cold hardiness than un-acclimated ones. Harris and Alex [15] demonstrated almost $100 \%$ survival of the diapause pupae at $2{ }^{\circ} \mathrm{C}$ and $80 \%$ mortality at $-17^{\circ} \mathrm{C}$ after gradual cooling. A low number of pupae survived even $-20^{\circ} \mathrm{C}$, which was in accordance with their field experiments and previous studies (e.g., $[27,28]$ ). Thus, we assume that all 'euphorbiae' pupae that entered diapause are able to gradually enhance their cold hardiness and cope even with subzero temperatures [11], while for 'tithymali', this ability should be remarkably constricted (own observations MG).

Despite scattered evidence of differences in cold survival and the indications of an underlying genetic regulation $[10,11]$, a clear association between temperature regime and phenotypic cold hardiness in different populations has not yet been systematically investigated. This would be an important basis to understand different physiological adaptations between lineages/ecotypes or formerly recognized species and subspecies in an elsewise over large geographic areas genetically uniform species [2]. The main goal of our study is thus to increase our understanding of how the two incipient subspecies, ecotypes, or lineages (not homologous with mitochondrial lineages) of H. euphorbiae, which are geographically as well as climatically constrained (e.g., [5], own observations MG) and genetically distinguished by two main mtDNA haplotype lineages, change their phenotype in biophysical characteristics, while being exposed to various experimentally simulated winter conditions. We use pupae for our tests, as the life stage with two different states, namely subitan (non-overwintering, cold sensitive) and diapause (overwintering, cold resistant).

The Hyles euphorbiae individuals of the ecotype consisting of 'euphorbiae' populations are expected to precisely follow the annual temperature and daylight cycle resulting in accentuated phenotypic differences between subitan and diapause pupae. In contrast, those from 'tithymali' populations are expected to be less synchronized with the daylight annual cycle and distinctly less cold tolerant, even if these pupae could be able to undergo cold hardening to some extent. To our knowledge, this has not yet been investigated in detail to date.

The null hypothesis $\mathrm{H}_{0}$ states that the environmental conditions of the pupae are the only factors determining cold hardiness: (i) Differences in light treatment leads to cold-hardy diapause (short-day regime) or cold-sensitive subitan (long-day regime) pupae; and (ii) differences in temperature, i.e., precooled or not precooled pupae, influence the degree of cold-hardiness. Thus, (i) larvae bred under long-day conditions develop to cold-sensitive subitan pupae with no difference between the two ecotypes $H$. euphorbiae 'euphorbiae' and 'tithymali'. Larvae bred under short-day conditions would be cold hardy, since they produce diapause pupae for overwintering, irrespective of which population they were from. (ii) Precooled diapause pupae (cold acclimation) would be cold hardier than pupae that were not precooled (irrespective of the population of origin). Hypothesis $\mathrm{H}_{1}$ states that certain differences in the genetic constitution of each ecotype determine the degree of cold hardiness in reaction to environmental conditions. The exact mechanism of underlying genetic/epigenetic determination (e.g., [10]) is beyond the scope of this paper. Thus, (i) pupae from 'euphorbiae' populations would differ from those of 'tithymali' in that they are generally more cold resistant. Conversely, they are able to react more appropriately to environmental signals and cold acclimation so that (ii) light regime and precooling would increase cold hardiness in 'euphorbiae' more than in 'tithymali'. (iii) Long-term winter conditions would lead to a stronger increase in cold hardiness in 'euphorbiae'. 
We measure supercooling ability and mortality of the pupae after different light and cooling regimes in order to test these hypotheses within and between the ecotypes. We expect that a combined effect of light (determines pupa type) and temperature (degree of acclimation) in the cold-adapted 'euphorbiae' populations would lead to a cold-resistant diapause pupae phenotype with the highest degree of cold hardiness.

With our experiments, we focus on the following basic questions for biological understanding:

Do we find evidence of phenotypic differences (supercooling, mortality) between ecotypes of $H$. euphorbiae, suggesting physiological adaptation as a basis for the observed lineage distribution? To which extent is H. euphorbiae (subitan as well as diapause pupae) resistant to decreasing (even subzero) external temperatures? Which conditions or their combination are crucial for triggering the switch between subitan and diapause pupae? How high is diapause mortality, and how long is diapause duration in different populations?

\section{Materials and Methods}

\subsection{Sampling}

Investigated pupae were bred as F1 and F2 generations from wild individuals (Table 1) sampled in three populations from the temperate climatic zone (Hyles euphorbiae 'euphorbiae' populations, abbr. Hee) and in two populations from subtropical climatic regions (Hyles euphorbiae 'tithymali' populations, Het).

Table 1. Localities of sampled wild H. euphorbiae F0 individuals used to breed progeny for the experiments. Hee-'euphorbiae' ecotype, Het-'tithymali'. See also the map in Appendix A.

\begin{tabular}{|c|c|c|c|c|c|c|}
\hline $\begin{array}{l}\text { Locality } \\
\text { Code }\end{array}$ & Locality Name & GPS Coordinates & $\begin{array}{l}\text { Climatic Zone } \\
\text { and Ecotype }\end{array}$ & $\begin{array}{c}\text { Date of } \\
\text { Sampling }\end{array}$ & $\begin{array}{l}\text { Sampled } \\
\text { Stage }\end{array}$ & Collectors \\
\hline $\mathrm{VH}$ & $\begin{array}{l}\text { Viernheimer Heide, } \\
\text { Hessen, Germany }\end{array}$ & $49^{\circ} 33^{\prime} \mathrm{N}, 8^{\circ} 32^{\prime} \mathrm{E}$ & Temperate Hee & 2014 & adult female & $\begin{array}{l}\text { B. Barth and R. } \\
\text { Schidlowski }\end{array}$ \\
\hline $\mathrm{CF}$ & $\begin{array}{l}\text { Cabeça Fundão, Fogo } \\
\text { island, Cape Verde }\end{array}$ & $14^{\circ} 54^{\prime} \mathrm{N}, 24^{\circ} 20^{\prime} \mathrm{W}$ & Subtropical Het & 2014 & larvae & B. Barth \\
\hline AT & $\begin{array}{c}\text { Altmühlthal, Bavaria, } \\
\text { Germany }\end{array}$ & $48^{\circ} 54^{\prime} \mathrm{N}, 11^{\circ} 06^{\prime} \mathrm{E}$ & Temperate Hee & 2015 & larvae & L. Langer \\
\hline MS & $\begin{array}{l}\text { Münnerstadt, Bavaria, } \\
\text { Germany }\end{array}$ & $50^{\circ} 14^{\prime} \mathrm{N}, 10^{\circ} 10^{\prime} \mathrm{E}$ & Temperate Hee & 2015 & larvae & H. Harbich \\
\hline Mad & $\begin{array}{c}\text { Madeira, Madeira } \\
\text { Archipelago, Portugal }\end{array}$ & $32^{\circ} 45^{\prime} \mathrm{N}, 17^{\circ} 00^{\prime} \mathrm{W}$ & Subtropical Het & 2015 & larvae & G. and B. Richter \\
\hline
\end{tabular}

Breeding was carried out in two consecutive years 2014 and 2015 (F1 and F2 generation). The breeding in the year 2014 came from a single female sampled using light trapping in Viernheimer Heide, Germany (representing Hee) and from larvae sampled on Fogo Island, Cape Verde (Het). In the year 2015, larvae caught in Altmühlthal and Münnerstadt, both Germany (Hee), and larvae originating from Madeira, Madeira Archipelago $(\mathrm{Het})$, were used for the breeding. Larvae used for breeding were kept at LD conditions (see below) until pupation. The pupae and emerging imagines were kept at room temperature (RT). Imagines were placed together (one female with one to three unrelated males) in flight cages at $23^{\circ} \mathrm{C}(\mathrm{RT})$ and fed with sugar solution ad libidum until mating and egg-laying. The first experimental generation (F1) of each lineage was bred from these two to three unrelated females (F0, Table 1).

\subsection{Larval Breeding}

For breeding, larvae were initially fed with Euphorbia segetalis Linnaeus 1753 or E. myrsinites Linnaeus 1753 leaves [10] and, once the L4 stage was reached, with a semiartificial $\operatorname{diet}([3,29]$ for details). 
The larvae from each ecotype and accordingly climatic region were divided into two groups and kept in a climate chamber (KB 720, Binder) under two different light conditions and uniform temperature regime, as follows:

- Long day (LD): $16.5 \mathrm{~h}$ light duration at $25^{\circ} \mathrm{C}$ and $7.5 \mathrm{~h}$ darkness at $23^{\circ} \mathrm{C}$, with a ramp time between light/dark of $1 \mathrm{~h}$.

- Short day (SD): For Het, $11 \mathrm{~h}$ light at $25^{\circ} \mathrm{C}$ and $13 \mathrm{~h}$ darkness at $23^{\circ} \mathrm{C}$, ramp time $1 \mathrm{~h}$, and for Hee, $13 \mathrm{~h}$ light at $25^{\circ} \mathrm{C}$ and $11 \mathrm{~h}$ darkness at $23^{\circ} \mathrm{C}$ with $1 \mathrm{~h}$ ramp time was needed to ensure larval prosperity (corresponding with natural September daylight lengths in Western African and Central European latitudes, respectively).

The humidity values were constantly $60 \%$ in both light regimes. When the larvae were ready to pupate, they were kept dark at RT until the beginning of the experiments.

\subsection{Cooling Treatments of the Pupae}

Immediately after the larvae entered the pupa stage, different cooling treatments were started. Starting and cooling down from an initial $23^{\circ} \mathrm{C}$, the cooling groups were held at $13{ }^{\circ} \mathrm{C}$ for one week, at $6{ }^{\circ} \mathrm{C}$ for one week (cooling group to $6{ }^{\circ} \mathrm{C}$ ) and at $-2{ }^{\circ} \mathrm{C}$ for one week (cooling group to $-2{ }^{\circ} \mathrm{C}$ ), including $24 \mathrm{~h}$ ramp times ( $36 \mathrm{~h}$ for the $-2{ }^{\circ} \mathrm{C}$ group), between the temperatures. Cooling treatments to $-10^{\circ} \mathrm{C}$ and long-term cooling treatment (LTC) were carried out only for the larvae reared at SD conditions. For these, one week at $-10^{\circ} \mathrm{C}$ followed, including a $72 \mathrm{~h}$ ramp time (cooling group to $-10^{\circ} \mathrm{C}$ ). The LTC groups received the whole cooling program until $-10^{\circ} \mathrm{C}$ and were then held for 3 months at $6{ }^{\circ} \mathrm{C}$, including 2-3 weeks of $-2{ }^{\circ} \mathrm{C}$ alternating with $6{ }^{\circ} \mathrm{C}$ weeks. The control groups were left to develop at $23^{\circ} \mathrm{C}$ (RT). Warming up of the mortality testing groups (and during the LTC program) proceeded in the exactly opposite way as the cooling scheme. All cooling treatments proceeded in small climate chambers (ICP 110, Memmert). All cold treatment groups are listed in Table 2.

Table 2. Overview and sample size of all studied groups (SCP analyses and mortality tests): Hee-'euphorbiae', Het'tithymali', LD-long-day breeding conditions, SD-short day, SCP control-without cold treatment, $6{ }^{\circ} \mathrm{C}$ and $-2{ }^{\circ} \mathrm{C}$-cold treatments, MT control-mortality test groups without cold treatment, $-10^{\circ} \mathrm{C}$-cooled mortality test groups, LTC-long-term cold treatment, $\mathrm{N}$-number of individuals per group.

\begin{tabular}{|c|c|c|c|c|}
\hline & Hee & & Het & \\
\hline Treatment (Total N = 225) & LD & SD & LD & SD \\
\hline SCP control & 17 & 16 & 16 & 16 \\
\hline $6^{\circ} \mathrm{C}$ & 17 & 16 & 16 & 16 \\
\hline$-2^{\circ} \mathrm{C}$ & 17 & 16 & 16 & 16 \\
\hline LTC & - & 16 & - & 14 \\
\hline \multicolumn{5}{|l|}{ MT (survived) } \\
\hline control & $17(17,100 \%)$ & $20(17,85 \%)$ & $20(20,100 \%)$ & $17(10,59 \%)$ \\
\hline control nondiapause/diapause & $17 / 0$ & $3 / 14$ ( $3<3$ months $)$ & $20 / 0$ & $3 / 7(1<3$ months $)$ \\
\hline$-10^{\circ} \mathrm{C}$ & - & $10(9,90 \%)$ & - & $8(5,63 \%)$ \\
\hline$-10^{\circ} \mathrm{C}$ nondiapause/diapause & - & $0 / 9$ & - & $0 / 5$ \\
\hline
\end{tabular}

\subsection{Experimental Design: SCP and Mortality Tests}

SCPs were measured at a total of 225 individuals (sex ratio $\mathrm{m} / \mathrm{f}=0.87$ ). Of each population, the individuals were distributed over three different groups of LD pupae (control, $6{ }^{\circ} \mathrm{C}$ and $-2{ }^{\circ} \mathrm{C}$ ) and four groups of SD pupae (control, $6{ }^{\circ} \mathrm{C},-2{ }^{\circ} \mathrm{C}$, and LTC) (Table 2). Individuals in each group were equally and randomly (with proportional sex ratios) divided into two subgroups-one subgroup was used for hemolymph extraction for calorimetric analyses to measure the hemolymph SCP in vitro and another one for in vivo SCP measurements on intact pupae. The cold-treated pupae were processed immediately after the cooling program was finished. Pupae from control groups were processed in 
the same way within a week after pupation. Hemolymph extractions were carried out by piercing with a sterilized scalpel into the wing disc of the pupae. Of the effluent liquid, $25 \mu \mathrm{L}$ was aliquoted and shock-frozen at $-80{ }^{\circ} \mathrm{C}$ for subsequent usage for calorimetric SCP determination.

Mortality was tested in six different groups: four groups of uncooled pupae (LD and SD of each ecotype) and, for comparison, two groups of the $-10{ }^{\circ} \mathrm{C}$ treatment of SD pupae (one per ecotype) (Table 2). The survival of cold-treated pupae (to $-10^{\circ} \mathrm{C}$ ) was checked after each cooling step. Presence of abdomen movement after mechanic irritation was used to diagnose a living pupa. Remaining control pupae were left to develop to check for baseline mortality, as well as for the duration of the pupa stage. For all mortality groups, duration of pupa stage and further survival in terms of successful hatching was recorded.

\subsection{In Vitro Calorimetric Hemolymph SCP Analyses}

Calorimetric in vitro SCP measurements of the $25 \mu \mathrm{L}$ pupa hemolymph were carried out by differential scanning calorimetry (DSC) $[30,31]$ with the hemolymph placed in a DSC micropan in a NETZSCH DSC 204F1 Phoenix 240 machine (SGS Institut FRESENIUS $\mathrm{GmbH}$, Dresden, Germany). This method measures the exothermic or endothermic energy change when matter changes its aggregation state, such as energy release by ice crystal formation, allowing to record the SCP, the temperature at which spontaneous freezing occurs in a supercooled system [18]. The sample was cooled down to $-40{ }^{\circ} \mathrm{C}$ by $1{ }^{\circ} \mathrm{C}$ per minute. The temperature, at which the exothermic energy peak was detected, represents the SCP $[25,31]$. The SCP value was measured two times for each sample to test if rethawing would change the result.

\subsection{In Vivo SCP of Entire Pupae}

The SCP of each pupa was also measured in vivo in the laboratory following Carrillo et al. [32,33]. In brief, polystyrene foam boxes (material Styrodur $3035 \mathrm{CS}$, density $33 \mathrm{~kg} / \mathrm{m}^{3}$, BASF) were constructed with a cavity drilled into the middle. The size of the box was constructed in a way that the temperature in the middle decreased by $1^{\circ} \mathrm{C}$ per minute when placed in a $-80^{\circ} \mathrm{C}$ freezer, starting with a box tempered at $0{ }^{\circ} \mathrm{C}$. One pupa was attached to a copper-constantan thermocouple (with freeze-stable tape stickers and high-vacuum grease to guarantee full contact) as a temperature detector and a YCT 4-channel data logger (Yu Ching Technology, Provider TC Mess- and Regeltechnik GmbH, Mönchengladbach Germany), and placed in each box. Afterwards, the box was closed with a silicon plug and placed into the freezer at $-80^{\circ} \mathrm{C}$. The temperature of the pupa was measured every $3 \mathrm{~s}$ until the sudden temperature rise (exothermic energy of freezing) was detected. This temperature corresponds to the SCP. The acclimation of the pupae to and back to $0{ }^{\circ} \mathrm{C}$ was conducted at the same rate $\left(1^{\circ} \mathrm{C}\right.$ per minute) immediately before and after the experiment. The survival of the pupae was checked immediately (controlling the presence/absence of abdomen movement after irritation).

The following statistical analyses were carried out using general linear models (GLM) in STATISTICA [34]. Since pupae mass differed between the sexes ( $t$-test, $\mathrm{t}=4.8, p<0.001$, mean male mass $=2.05 \mathrm{mg}$, mean female mass $=2.28 \mathrm{mg}$, mean total mass $=2.18 \mathrm{mg}$, see Appendix B), we tested for an influence of sex or pupal body mass on the SCP results by running a GLM model with sex nested within ecotypes and setting the pupal mass as a covariate of sex. For both in vitro and in vivo SCP measures, the model showed no significant effect of sex (see also [35]) or mass (whole model SCP in vitro: $\mathrm{R}^{2}=0.03, p=0.67$; in vivo: $R^{2}=0.07, p=0.23$ ). Thus, we used simple GLM models further on to test for differences of SCP data across all test groups. 


\section{Results}

\subsection{In Vitro Calorimetric Hemolymph SCP Analyses}

The two subsequent SCP measurements that were carried out to test for an effect of cooling and rethaw were significantly in line (linear regression, $R^{2}=0.88, p<0.001$ ). Therefore, only the first measurement was used for further analyses.

The mean $\mathrm{SCP}$ values of the hemolymph varied between $-14.9^{\circ} \mathrm{C}$ and $-21.0^{\circ} \mathrm{C}$ (see Appendix $\mathrm{B}$ for details) with a significant effect of the 14 different test groups (ANOVA, $\mathrm{F}=5.71, p<0.001$ ) (Figure 1). The highest SCP were detected for the uncooled LD pupae groups of 'tithymali' (Het: mean $=-14.9^{\circ} \mathrm{C}+/-1.07$ standard deviation) and 'euphorbiae' populations (Hee: $-15.3{ }^{\circ} \mathrm{C}+/-0.33$ ). Analyzing the pairwise comparisons among all groups showed an interesting general trend: all SD pupae and the cooled LD pupae of Het seem to have similarly low SCP, compared to the LD groups of Hee, no matter whether cooled or uncooled. The contrast between the LD Het control and cooled groups is remarkable (Figure 1), even though not all pairwise post hoc tests (Bonferroni) are significant. However, some significant post hoc comparisons between SD and LD groups confirm this trend. Namely, the $6{ }^{\circ} \mathrm{C} \mathrm{SD} \mathrm{Hee} \mathrm{group,} \mathrm{both} \mathrm{cooled} \mathrm{SD} \mathrm{Het} \mathrm{groups} \mathrm{and} \mathrm{both}$ SD long-term cooled groups differ significantly from the LD control groups of both Hee and Het. The long-term cooled SD Hee group differed as well from each of the cooled LD Hee groups (Figure 1). GLM models testing for the separate effects of ecotype, day length, and cooling across all groups (excluding the long-term groups, since only SD was tested here) showed significant effects of all three factors (Table 3). However, testing within the lineages showed only day length to be a significant factor for Hee, while day length and cooling were significant for Het (Table 3). Tests among only the SD groups (including long term) showed no significant effect of lineage or cooling, confirming the light regime to have an overall important effect on cold hardening.

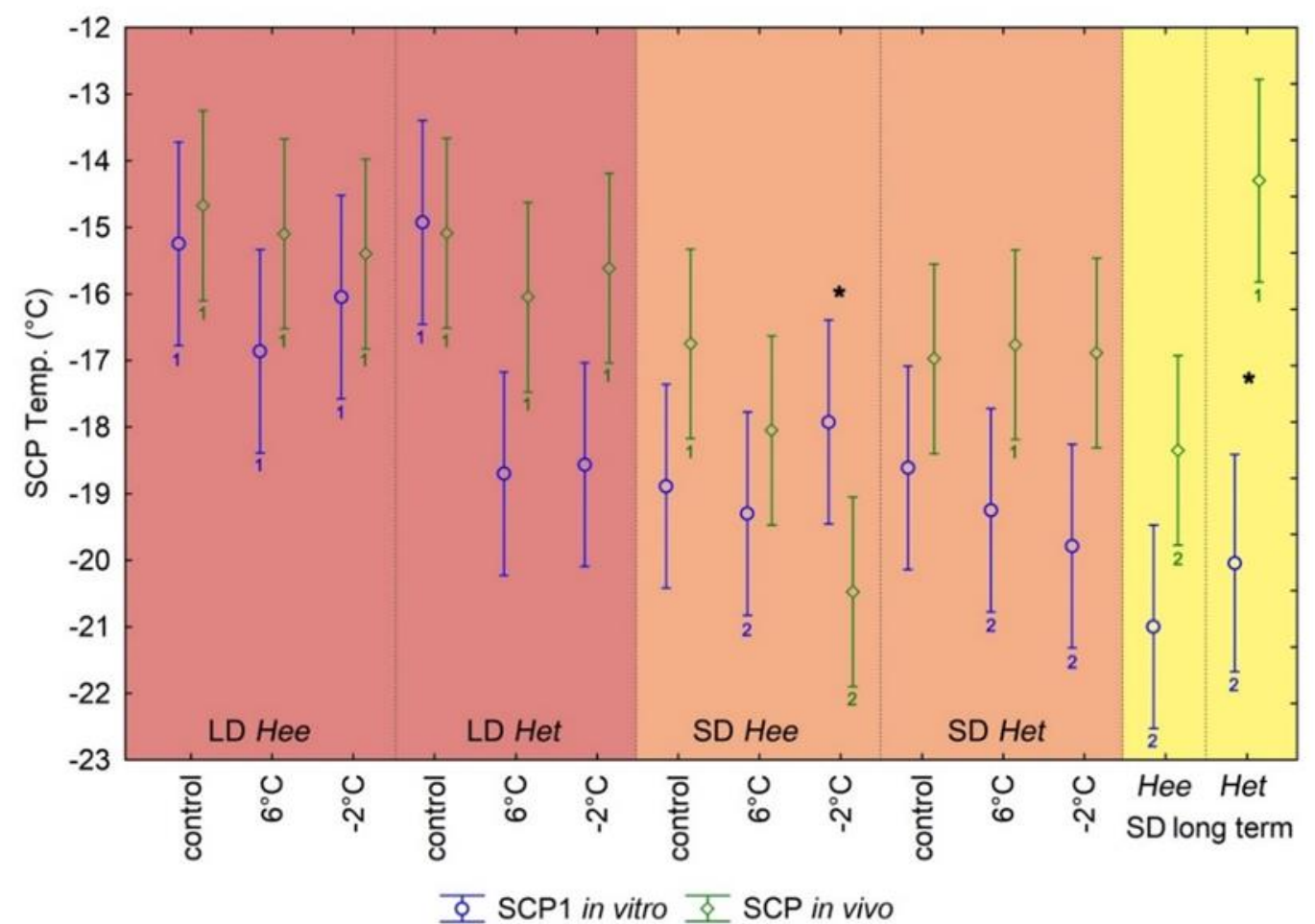

Figure 1. Average SCP values for all studied groups +/ -95\% confidence intervals. Blue circle: Hemolymph SCP value of the first in vitro measurements. Green diamonds: Entire pupae in vivo SCP measurements. Numbers under the bars denote significant comparisons of the Bonferroni post hoc tests. Different numbers of the same color show significant pairwise differences between at least two of these groups for the respective SCP measurement (see text for more details). Asterisks denote significant pairwise differences between the different SCP measurements of the same test group. 
Table 3. Results of the GLM models showing the significances of the effects of the different H. euphorbiae ecotypes, the day length, and the cooling regime on the SCP measurements. ${ }^{*}-p<0.05,{ }^{* *}-p<0.01,{ }^{* * *}-p<0.001$, n.s. - not significant.

\begin{tabular}{|c|c|c|c|c|}
\hline \multirow[t]{2}{*}{ Effect } & \multirow{2}{*}{$\frac{\text { SCP In Vitro }}{F}$} & \multicolumn{3}{|c|}{ SCP In Vivo } \\
\hline & & Significance & $F$ & Significance \\
\hline Ecotype & 4.55 & $*$ & 1.26 & n.s. \\
\hline Day length & 26.45 & $* * *$ & 32.09 & $* * *$ \\
\hline Cooling group & 4.91 & $* *$ & 2.43 & n.s. \\
\hline \multicolumn{5}{|l|}{ Within Hee } \\
\hline Day length & 17.57 & $* * *$ & 25.05 & $* * *$ \\
\hline Cooling group & 1.22 & n.s. & 2.91 & n.s. \\
\hline \multicolumn{5}{|l|}{ Within Het } \\
\hline Day length & 9.35 & $* *$ & 7.80 & $* *$ \\
\hline Cooling group & 6.70 & $* *$ & 0.22 & n.s. \\
\hline \multicolumn{5}{|l|}{ Within SD } \\
\hline Ecotype & 0.06 & n.s. & 20.02 & $* * *$ \\
\hline Cooling group & 1.66 & n.s. & 4.30 & $* *$ \\
\hline
\end{tabular}

\subsection{In Vivo SCP Measurements on Entire Pupae}

The pupae for the SCP in vivo measurements received the same treatment and were thus divided into the same treatment groups as the in vitro hemolymph measurement pupae (Table 2). All pupae for which the SCP of the entire pupa was measured were dead at the end of the measurements, indicating no survival of actual body tissue freezing. The SCP values measured with the thermocouple detectors on the pupae in vivo reached mean temperatures between $-14.3^{\circ} \mathrm{C}$ and $-20.5{ }^{\circ} \mathrm{C}$ (see Appendix $\mathrm{B}$ for details) with a significant effect of the 14 different test groups (ANOVA, $\mathrm{F}=5.49, p<0.001$ ) (Figure 1). SCP values were mostly slightly higher (almost identical for the control groups) but not significantly different than the respective values obtained by the in vitro analyses (pairwise $t$-tests, Bonferroni corrected), with two interesting exceptions: The SD Het long term in vivo group had a strongly and significantly higher SCP than in vitro $\left(-14.3{ }^{\circ} \mathrm{C}+/-1.61\right.$ to $\left.-20.0{ }^{\circ} \mathrm{C}+/-2.62, p<0.001\right)$. In contrast, the SD Hee group precooled to $-2{ }^{\circ} \mathrm{C}$ had a significantly lower SCP than the respective in vitro group $\left(-20.5^{\circ} \mathrm{C}+/-1.81\right.$ to $\left.-17.9^{\circ} \mathrm{C}+/-1.67, p=0.008\right)$, even though this latter comparison was slightly not significant after Bonferroni correction. A correlation between the in vitro and the in vivo SCP values (correlation coefficient $=0.43, p<0.05$ ) shows these two values to be clearly outside of the $95 \%$ confidence interval (Figure 2).

Interestingly, the Bonferroni pairwise comparisons among the in vivo groups indicate a different trend than the in vitro comparisons. Here, only the SD Hee group precooled to $-2{ }^{\circ} \mathrm{C}$ reaches a significantly lower SCP than almost all other groups (significant difference to groups marked with a green no. 1 in Figure 1). Furthermore, the long-term cooled SD Hee group had a significantly lower in vivo SCP than the long term SD Het group. Accordingly, the latter does not differ from the Het control groups, in contrast to the in vitro results. Analogously to the in vitro results, GLM models testing the effects of ecotype, day length and cooling separately across all groups confirm a significant effect of day length for both ecotypes but a particular effect of ecotype and significant effect of cooling among the $\mathrm{SD}$ in vivo groups (Table 3). 


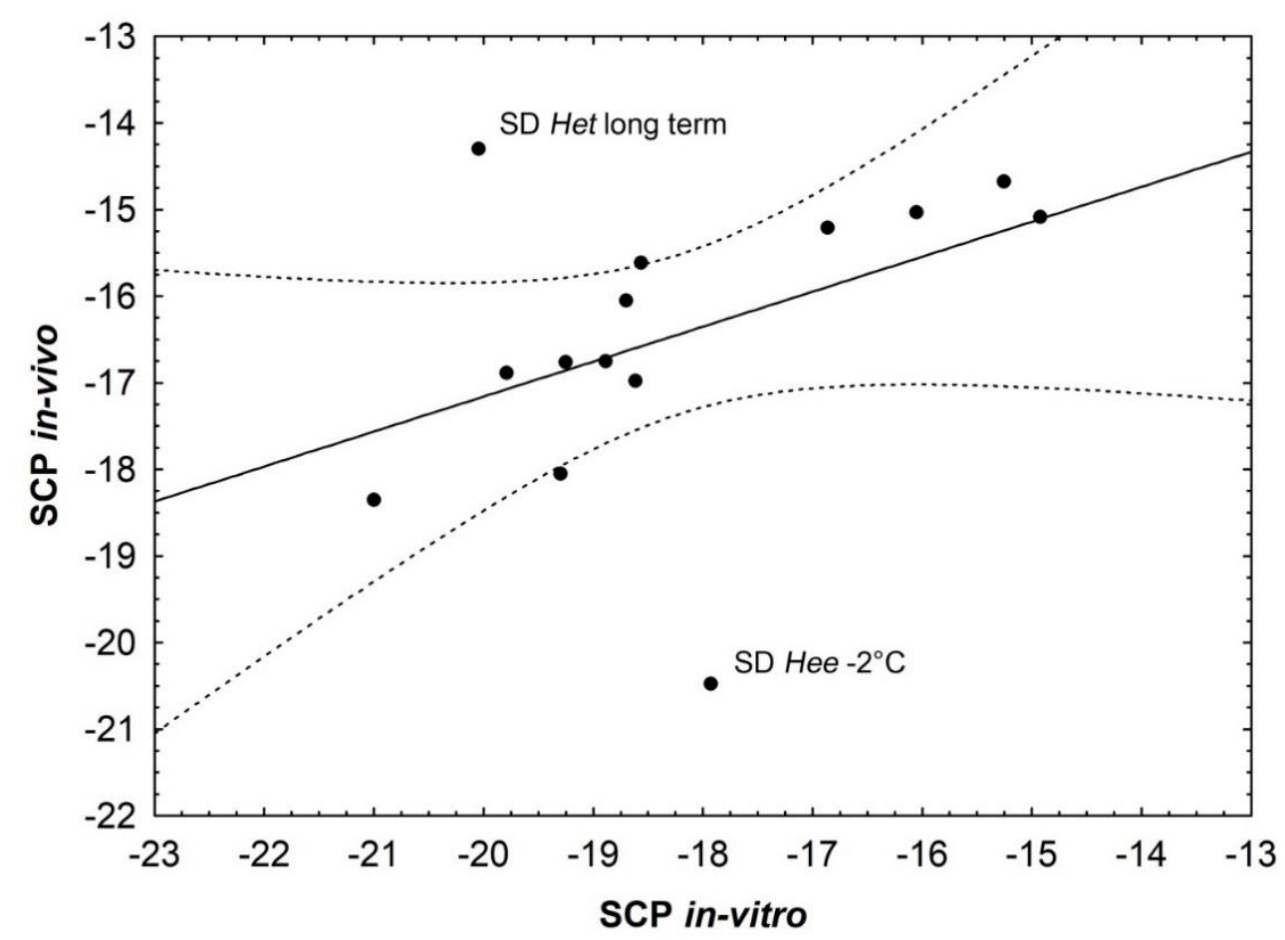

Figure 2. A correlation between the in vitro and the in vivo SCP values (correlation coefficient $=0.43, p<0.05$ ) shows the two groups that differ strongly between the two different measurements as clearly outside of the $95 \%$ confidence interval (dashed lines) of the correlation.

\subsection{Mortality Tests}

Six different groups of pupae were used for mortality tests (see Table 2 for details). The LD control individuals yielded only subitan pupae, regardless of population origin. The duration of the pupal stage of both LD groups varied between 18 and 24 days (mean 20 days), with $100 \%$ survival.

The SD control pupae showed a mixture of diapause and subitan pupae, with $82 \%$ diapause among the surviving pupae in Hee and $78 \%$ in the Het. The duration of the remaining subitan pupal stage was slightly longer than in LD groups, varying between 27 and 35 days (mean 31.5 days). There was a clear difference in the duration of subitan and diapause pupa stages with diapause ranging from 86 to 438 days (mean 272 days for Hee and 277 days for Het, respectively). Occasionally, in Het, the diapause can even last from more than one up to several years (own observation). Total survival in terms of successful emergence among the Hee samples was $85 \%$, whereas only $59 \%$ of the Het pupae survived and emerged successfully.

SD pupae from both populations cooled to $-10{ }^{\circ} \mathrm{C}$ had $100 \%$ diapause between 107 and 559 days (mean 195 days for Hee and 289 days for Het, respectively). Survival rate in cooled SD groups was $90 \%$ for Hee and $63 \%$ for Het. Thus, Hee and Het had an about similar survival rate of cooled and uncooled pupae under SD conditions, respectively, while the total survival rate under SD conditions was higher in Hee (85-90\%) compared to Het $(59-63 \%)$.

\section{Discussion}

The main results of this study demonstrate combined phenotypic effects of day length, cold regime, and different $H$. euphorbiae ecotypes, Hee and Het, with respect to the ability to supercool cold-hardy diapause pupae, accompanied by different survival rates of the cold-hardy pupa stage of Hee and Het. Phenotypic changes during cold hardening of $H$. euphorbiae (Hee) have already been proposed on the basis of protein metabolic [11] and transcriptomic [10] changes. Furthermore, older studies have investigated phenotypic 
effects of day length [12] or cold ([15] for Hee, [14] for Het) in diapause separately. However, the combined effects, including implications on H. euphorbiae ecotype adaptation [1-7] and the possible cold (even subzero) acclimation and cold-induced diapause of Het, have not been investigated yet.

\subsection{In Vitro and In Vivo SCP Analyses}

Comparing all SCP in vitro values, LD precooled groups of Het together with all SD pupae of both ecotypes clearly reach lower levels (Figure 1) than LD control groups and LD precooled pupae of Hee. This corroborates the trend that precooling without an additional influence of the light regime lowers the SCP particularly in Het, while rather a combined effect of light and cooling affects the hemolymph SCP in Hee. Evidently, the cold temperature stimulus facilitates the occurrence of freeze-insusceptible hemolymph, but only in Het populations the temperature stimulus alone initiates the maximal SCP decrease. This seems to be an effective adaptation in Het regions, where the lowest temperatures are not so extreme, come less regularly and/or are not strictly joined with other external factors such as pronounced daylight duration changes [36,37]. On the other hand, in regions such as Central Europe, where the subzero temperatures appear regularly, an early reaction on the usual environmental day-length shortening gives a higher chance to acclimate the phenotype on-time to upcoming unfavorable frosty seasonal conditions [11,38]. During long-day conditions, the (extreme) cold temperatures are not usual and therefore not prepared for. Consequently, we suppose no hereditary adaptation enabling a sudden distinctive SCP decrease. The results of all LD Hee groups corroborate this. We presume that a higher number of studied individuals would further elucidate these trends.

Comparing SCP values obtained from in vitro and in vivo measurements for particular groups, nearly the same values were measured only for both LD controls (Figure 1), which were the only groups developing without any stress-signalizing factors. Moreover, their values do not differ for Hee and Het individuals. Therefore, we conclude that both ecotypes are similar in subitan pupal states. They have widely overlapping temperature optima and their SCP values cannot be discriminated, implying a similar frost resistance for un-acclimated populations.

For all other groups, the in vivo values tend to be slightly, even though not significantly, higher, or in case of the long-term cooled SD Het group even strongly, significantly higher, than the in vitro values, with the one exception of the remarkably lower in vivo SCP of the SD Hee pupae cooled to $-2{ }^{\circ} \mathrm{C}$ (Figure 2, discussed below). This may indicate that not only the hemolymph, but also intracellular cryoprotection of body tissue, e.g., through the production of antifreeze proteins and carbohydrates [23-25,39], participates in the resulting frost-resistant phenotype of the whole individual. Similarly, no pronounced tendency of SCP changes depending on decreasing temperatures of prior cold treatment can be observed for in vitro hemolymph values. On the other hand, comparing in vivo values for Hee vs. Het populations, only in the SD Hee group the SCP decrease associated with precooling temperature decrease is apparent in contrast to SD Het or the LD groups, where this effect or any other clear tendency is not recognizable. This can be interpreted as a highly targeted reaction of Hee populations on stress intensity caused by lowering temperatures and stands in contrast to the less specific reaction of Het populations, e.g., [40,41]. Concluding the long-term SCP results, the observed higher, yet still low, in vivo SCP value in the Hee group may represent the optimally adjusted level of protection according to longer-lasting intensity of temperature stress. Furthermore, the Hee long term SCP value is significantly lower compared to Het. Therefore, in Het the mechanism to achieve long-term freeze avoidance of the whole pupa (hemolymph and body tissue) is probably modified/lacking, which is manifested as a high in vivo SCP value as for untreated control groups. These differences are supported by the results of ANOVA post hoc tests (Bonferroni) as indicated in Figure 1.

The SD Hee samples precooled to $-2{ }^{\circ} \mathrm{C}$ reached the lowest in vivo SCP value of all groups, and it differs from its respective control group (in contrast to the $6{ }^{\circ} \mathrm{C}$ cooled 
group), ascertaining a SCP decrease in relation to precooling temperature for Hee under SD conditions. This suggests that the adaptation to subzero outer temperatures in Hee populations is specific (in comparison with Het populations) and is not limited only to the hemolymph frost resistance.

The in vivo SCP results clearly demonstrate the actual biologically relevant phenotype of the pupae [11]. Accordingly, all pupae were dead after the end of the SCP measurement, confirming freeze susceptibility and cold survival based on lowering the SCP.

Thus, we propose an adaptive freeze avoidance strategy and seasonal cold hardening $[18,42-44]$ in the Hee populations of H. euphorbiae. The Het population, in contrast, appears to exhibit a rather opportunistic strategy of chill tolerance enabling it to react more flexibly to temporary unfavorable environments, independently of further external conditions, by lowering the hemolymph SCP if exposed to cold, but without a long-term prepared metabolic change of the whole pupa. This kind of variability is often observed between closely related species or populations of the same species in different climate zones [44-46].

Seasonal cold hardening under climatic conditions with seasonal winters is often achieved by long-term prepared metabolic changes during diapause development, induced by a combined effect of day length and decreasing temperature [20,21,46-48]. This results in the biochemical accumulation of carbohydrate cryoprotective substances, which lower the SCP (such as sugars and polyols), and increased stress tolerance of cell tissue [10,18,23-25,38,44,49]. Even though we have no direct evidence for such metabolic changes, we assume a seasonal adaptive metabolic mechanism in the Hee pupae. For example, Barth et al. [10] showed transcriptomic signals of changes in the carbohydrate metabolism and cell signaling, as well as metabolic depression of the energy expensive respirator metabolism in $H$. euphorbiae Hee populations-all signals of seasonal diapause acclimation [50,51]. Lowered SCPs during diapause have as well been related to cold hardiness and the presence of biochemical cryoprotectants in various Lepidoptera and other insects [20,35,52-55]

\subsection{Mortality Tests and Survival Strategies in Pupa Stage}

Sufficiently long daylight durations together with warm ambient temperatures are clearly recognized as favorable living conditions during the pre-adult life-stages of insects $[22,37,44]$. This facilitates quick development to adults, which was fully confirmed for all our tested LD individuals (Table 2).

On the other hand, lowering ambient temperatures together with short-day conditions are interpreted as upcoming inconvenient living conditions and unambiguously trigger the diapause in all tested individuals. These two factors are assumed to be crucial in most studies dealing with seasonal ecology in insects, e.g., [56-58]. In several insect groups including Lepidoptera, e.g., [57,59-61] and references therein, geographic variation of critical conditions determining diapause and its intensity or duration was ascertained among different populations. In H. euphorbiae, variability of duration of the diapause between both ecotypes was detected. The Hee populations periodically come in contact with cold inconvenient seasons (winter) within an expectable time span, and they accordingly optimized the duration of the diapause. In contrast, the Het populations more likely face less predictable seasonal changes (including cold, dry, or wet periods), which probably advance faster and with less explicit signals beforehand. Higher variability in diapause duration can be useful to increase the chance that at least some individuals achieve successful reproduction. Nevertheless, more test individuals would be needed to corroborate the observed trend in diapause length duration.

Short-day test conditions without a period of a low temperature stimulus do not correspond with common natural conditions of Hee. Accordingly, we observed overall raised mortality, which however, does not change much under additionally cooled conditions and is considerably lower in Hee compared to Het (survival $85 \%$ uncooled vs. 90\% cooled in Hee and 59\% uncooled vs. 63\% cooled in Het) (Table 2). This supposedly lower "baseline 
mortality" of SD pupae in Hee supports the idea of a better-adapted phenotype of the Hee ecotype diapause pupae to survive seasonal cold conditions.

Lacking the low-temperature impulse, a fraction of the pupae of both ecotypes is not able to switch to diapause, developing subitan pupae with slightly prolonged development instead (on average 11 days longer), probably due to difficulties to react properly, if receiving conflicting outer signals (Table 2). These results underline the importance of both short-day lengths and temperature decrease for appropriate diapause progress.

Persistent shifts of such environmental conditions, such as ongoing temperature changes during global warming, may thus lead, in turn, to a shift in the distribution of ecotypes $[37,44]$. In insects with a short generation time, such changes can pass during several decades, as this was, e.g., documented by tracing the genetic composition of $H$. euphorbiae populations from Italy over the past 120 years [7]. In other studies dealing with insects [62,63], the effect of climatic changes was simulated in order to estimate changes in survival success. Increased winter temperatures or heat waves during the cold phase reduced overwintering success [63] and even post-diapause reproductive potential [62]. Our findings and previously published phylogeographical studies $[2,3,6]$ thus allow for expectations of shifts in distribution area, contact zones, and ecotype prevalence in $H$. euphorbiae. The ecotypes, which are able to cope with stronger weather fluctuations, but not necessarily extremely low temperatures, are expected to colonize more northern areas (e.g., Central Europe). On the other hand, cold-hardy ecotypes would be able to survive in Northern Europe, where nowadays only single individuals are rare guests without stable populations $[1,64]$. However, further changes of other factors or their combination, e.g., humidity, may have unpredictable influences on the population dynamics [63].

Further studies on the presence of biochemical cryoprotective substances in differentially treated pupae are expected to further elucidate the exact physiological mechanisms underlying cold hardiness in H. euphorbiae, as well as its potential ecotype dynamics.

\section{Conclusions}

Based on the results of our analyses, we propose two regulation mechanisms controlling low-temperature resistance in H. euphorbiae.

The first approach includes short-term hemolymph changes regulated through the sensitivity of the late larva instar and/or early pupa (supposedly the first activated response in Hee) to daylight duration shifts, also induced by low-temperature stress alone (proposed main responsible pathway for the cold-stress feedback in Het). This defense is present in all individuals regardless of population origin and may evoke an opportunistic or short-term cold tolerance [42-44]. The resulting phenotype is slightly more cold acclimated than the subitan pupae but possibly not able to provide long-term cold resistance. Despite this, the ability for cold acclimation, including subzero temperatures, leading to cold-induced diapause was ascertained also for Het populations, which was not known before.

Only the additional effect of cold/lowering temperature following short day conditions may trigger the second mechanism, which is necessary to reach an appropriate efficient and long-persisting cold tolerance in terms of a seasonal cold hardening [21,22,47-49]. This ability, due to a combined effect of light and cooling regime, was detected only for the Hee ecotype. Thus, our results support the hypothesis $\mathrm{H}_{1}$, stating that there are differences between the ecotypes of $H$. euphorbiae in their responses to cold stress, which can be detected as different extents of cold hardiness in each of the two ecotypes. These phenotypic differences correspond with the influence of diverse climatic living conditions of each population. In the frosty winter season, the appropriate longstanding cold tolerance is crucial. By contrast, in rather moderate climates with less predictable weather changes, but no hard winter, the occasional change to diapause helps to survive stochastic unfavorable conditions.

Even though these distinguished environmental conditions may facilitate an incipient species differentiation process [1], persisting similar optima of living requirements, climatic fluctuations, and good mobility of adult individuals can act in the opposite way, enabling 
contact, hybridization, and gene flow between ecotypes. This may explain the apparent genetic unity of all populations of $H$. euphorbiae despite adaptation to different climatic conditions [2]. For the accurate understanding of ongoing processes, further studies are needed.

Author Contributions: Conceptualization, A.K.H. and M.B.B.; methodology, A.K.H. and M.B.B.; experimental lab work, M.B.B.; formal analysis, M.B.B. and H.D.; investigation, M.B.B., H.D., A.K.H.; resources, A.K.H.; data curation, H.D., M.B.B. and A.K.H.; writing-original draft preparation, H.D.; writing-review and editing, H.D., M.B.B., A.K.H. and M.G.; visualization, M.B.B.; supervision, A.K.H.; project administration, A.K.H. All authors have read and agreed to the published version of the manuscript.

Funding: This research received no external funding; it was financed by an internal institutional Senckenberg budget.

Institutional Review Board Statement: Not applicable.

Informed Consent Statement: Not applicable.

Data Availability Statement: The complete SCP dataset is available in Appendix B. For other data please contact the authors.

Acknowledgments: We thank M. Wink for his indispensable role as mentor when A.K.H. started working on the genus Hyles during 2000-2005. For contributing samples and help in the field we thank the late H. Harbich, L. Langer, J. Lopez, G. and B. Richter, and R. Schidlowski. J. Lopez provided valuable organization and guidance during the sampling on Cape Verde Islands. For help in the lab and with animal breeding, we thank K. Buchwalder, L. Langer, and A. Rauh. For further valuable discussions, we thank H. Stuckas and R. Ernst. We are very thankful to M. Böhme and B. Mehlich (Microelectronics, SGS Institut FRESENIUS GmbH, Königsbrücker Landstrasse 161, D-01109 Dresden, Germany) for calorimetric analyses of hemolymph samples. We thank E. Marabuto for creating the map showing localities of the F0 individuals sampled. The publication of this article was funded in part by the Open Access Fund of the Leibniz Association.

Conflicts of Interest: The authors declare no conflict of interest.

\section{Appendix A}

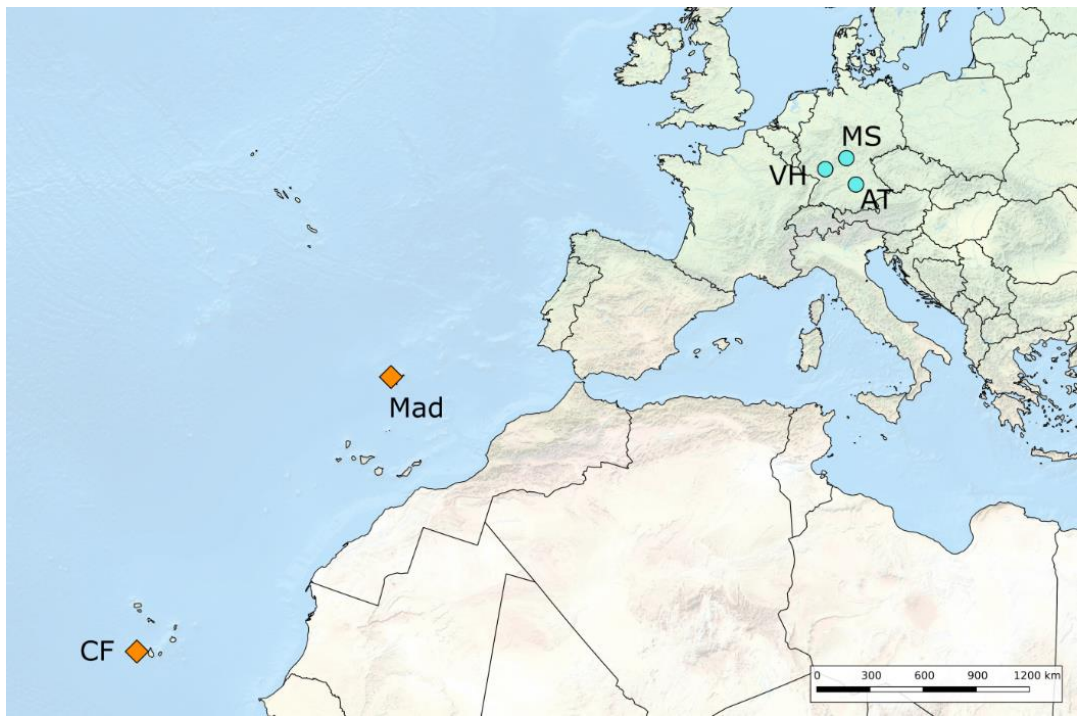

Figure A1. Map of localities of sampled wild H. euphorbiae F0 individuals used to breed progeny for the experiments. Orange diamonds: Het ecotype, blue circles: Hee. Locality codes according to Table 1. Map built using QGIS 2.18.4 (qgis.org, accessed on 15 Mrch 2021), edited using Inkscape 1.0.1 (inkscape.org, accessed on 15 Mrch 2021). 


\section{Appendix B}

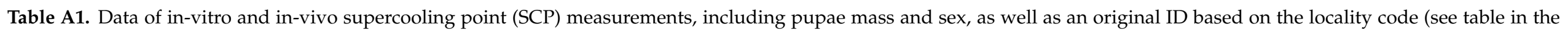
original text).

\begin{tabular}{|c|c|c|c|c|c|c|c|c|c|c|c|c|c|}
\hline \multicolumn{7}{|c|}{ In-Vitro } & \multicolumn{7}{|c|}{ In-Vitro } \\
\hline Ecotype & Day Length & Treatment & ID Sample & Sex & Mass (g) & SCP & Ecotype & Day Length & Treatment & ID Sample & Sex & Mass (g) & SCP \\
\hline $\mathrm{Hee}$ & LD & control & VH31 & $\mathrm{f}$ & 2.34 & -15.9 & $\mathrm{Hee}$ & LD & control & VH015 & $\mathrm{m}$ & 1.588 & -14.7 \\
\hline $\mathrm{Hee}$ & LD & control & VH32 & $\mathrm{f}$ & 2.443 & -15.5 & $\mathrm{Hee}$ & LD & control & VH035 & $\mathrm{m}$ & 2.707 & -15.2 \\
\hline Hee & LD & control & VH26 & $\mathrm{m}$ & 2.028 & -14.9 & Hee & LD & control & VH041 & $\mathrm{f}$ & 1.961 & -16.2 \\
\hline Hee & LD & control & VH27 & $\mathrm{m}$ & 2.273 & -15.4 & Hee & LD & control & SA001 & $\mathrm{m}$ & 1.077 & -15 \\
\hline Hee & LD & control & VH23 & $\mathrm{m}$ & 1.657 & -14.9 & Hee & LD & control & SA002 & $\mathrm{f}$ & 2.533 & -14.7 \\
\hline Hee & LD & control & VH49 & $\mathrm{f}$ & 2.298 & -15.3 & $\mathrm{Hee}$ & LD & control & SA003 & $\mathrm{m}$ & 2.011 & -16.3 \\
\hline Hee & LD & control & VH16 & $\mathrm{m}$ & 2.305 & -14.8 & $\mathrm{Hee}$ & LD & control & SA004 & $\mathrm{f}$ & 1.943 & -7.3 \\
\hline Hee & LD & control & VH19 & $\mathrm{m}$ & 1.923 & -15.3 & Hee & LD & control & SA005 & $\mathrm{m}$ & 1.959 & -18 \\
\hline Hee & LD & control & VH03 & $\mathrm{m}$ & 2.76 & -15.3 & Hee & LD & $6^{\circ} \mathrm{C}$ & VH021 & $\mathrm{f}$ & 2.117 & -16.7 \\
\hline Hee & LD & $6^{\circ} \mathrm{C}$ & VH28 & $\mathrm{m}$ & 2.512 & -16.2 & Hee & LD & $6{ }^{\circ} \mathrm{C}$ & VH030 & $\mathrm{f}$ & 2.262 & -16.1 \\
\hline Hee & LD & $6{ }^{\circ} \mathrm{C}$ & VH39 & $\mathrm{m}$ & 2.393 & -18.4 & $\mathrm{Hee}$ & LD & $6^{\circ} \mathrm{C}$ & VH036 & $\mathrm{f}$ & 2.207 & -8.2 \\
\hline Hee & LD & $6^{\circ} \mathrm{C}$ & VH42 & $\mathrm{f}$ & 2.206 & -14.6 & Hee & LD & $6^{\circ} \mathrm{C}$ & VH038 & $\mathrm{f}$ & 2.373 & -16.5 \\
\hline $\mathrm{Hee}$ & LD & $6{ }^{\circ} \mathrm{C}$ & VH43 & $\mathrm{f}$ & 2.38 & -15.4 & $\mathrm{Hee}$ & LD & $6^{\circ} \mathrm{C}$ & VH040 & $\mathrm{f}$ & 2.766 & -15.1 \\
\hline Hee & LD & $6^{\circ} \mathrm{C}$ & $\mathrm{VH} 29$ & $\mathrm{~m}$ & 2.006 & -16.7 & Hee & LD & $6^{\circ} \mathrm{C}$ & VH045 & $\mathrm{f}$ & 2.673 & -17.2 \\
\hline $\mathrm{Hee}$ & LD & $6^{\circ} \mathrm{C}$ & VH08 & $\mathrm{f}$ & 2.644 & -18.6 & $\mathrm{Hee}$ & LD & $6^{\circ} \mathrm{C}$ & VH001 & $\mathrm{m}$ & 2.644 & -15.8 \\
\hline Hee & LD & $6^{\circ} \mathrm{C}$ & VH09 & $\mathrm{f}$ & 2.517 & -15.1 & Hee & LD & $6^{\circ} \mathrm{C}$ & VH012 & $\mathrm{m}$ & 1.729 & -15.2 \\
\hline $\mathrm{Hee}$ & LD & $6{ }^{\circ} \mathrm{C}$ & VH14 & $\mathrm{f}$ & 2.655 & -19.9 & Hee & LD & $6{ }^{\circ} \mathrm{C}$ & VH024 & $\mathrm{m}$ & 1.942 & -16.1 \\
\hline Hee & LD & $-2{ }^{\circ} \mathrm{C}$ & VH83 & $\mathrm{f}$ & 1.939 & -15.6 & Hee & LD & $-2{ }^{\circ} \mathrm{C}$ & VH047 & $\mathrm{f}$ & 2.301 & -10.6 \\
\hline $\mathrm{Hee}$ & LD & $-2{ }^{\circ} \mathrm{C}$ & VH90 & $\mathrm{f}$ & 2.282 & -15 & Hee & LD & $-2^{\circ} \mathrm{C}$ & VH052 & $\mathrm{f}$ & 2.071 & -13.7 \\
\hline Hee & LD & $-2^{\circ} \mathrm{C}$ & VH80 & $\mathrm{f}$ & 2.423 & -16.5 & Hee & LD & $-2{ }^{\circ} \mathrm{C}$ & VH055 & $\mathrm{f}$ & 2.474 & -15.1 \\
\hline $\mathrm{Hee}$ & LD & $-2{ }^{\circ} \mathrm{C}$ & VH76 & $\mathrm{f}$ & 2.6 & -15.7 & $\mathrm{Hee}$ & LD & $-2{ }^{\circ} \mathrm{C}$ & VH056 & $\mathrm{f}$ & 2.206 & -16.3 \\
\hline Hee & LD & $-2{ }^{\circ} \mathrm{C}$ & VH78 & $\mathrm{m}$ & 1.988 & -17.3 & $\mathrm{Hee}$ & LD & $-2{ }^{\circ} \mathrm{C}$ & VH070 & $\mathrm{f}$ & 1.215 & -18.1 \\
\hline Hee & LD & $-2^{\circ} \mathrm{C}$ & VH79 & $\mathrm{m}$ & 1.729 & -17.7 & Hee & LD & $-2^{\circ} \mathrm{C}$ & VH060 & $\mathrm{m}$ & 2.622 & -17.2 \\
\hline Hee & LD & $-2^{\circ} \mathrm{C}$ & VH87 & $\mathrm{m}$ & 2.138 & -17.4 & Hee & LD & $-2{ }^{\circ} \mathrm{C}$ & VH066 & $\mathrm{m}$ & 2.053 & -16.8 \\
\hline Het & LD & control & CF37 & $\mathrm{m}$ & 2.478 & -16.3 & Hee & LD & $-2^{\circ} \mathrm{C}$ & VH077 & $\mathrm{m}$ & 2.27 & -12.1 \\
\hline Het & LD & control & CF65 & $\mathrm{f}$ & 2.143 & -16.2 & Het & LD & control & CF005 & $\mathrm{f}$ & 2.707 & -16 \\
\hline Het & LD & control & CF80 & $\mathrm{f}$ & 2.776 & -13.6 & Het & LD & control & CF009 & $\mathrm{f}$ & 2.06 & -15.1 \\
\hline Het & LD & control & CF91 & $\mathrm{f}$ & 1.867 & -15.2 & Het & LD & control & CF017 & $\mathrm{f}$ & 2.398 & -14.7 \\
\hline
\end{tabular}


Table A1. Cont.

\begin{tabular}{|c|c|c|c|c|c|c|c|c|c|c|c|c|c|}
\hline \multirow[b]{2}{*}{ Ecotype } & \multicolumn{6}{|c|}{ In-Vitro } & \multicolumn{7}{|c|}{ In-Vitro } \\
\hline & Day Length & Treatment & ID Sample & Sex & Mass (g) & SCP & Ecotype & Day Length & Treatment & ID Sample & Sex & Mass (g) & SCP \\
\hline Het & LD & control & CF76 & $\mathrm{m}$ & 1.369 & -15.3 & Het & LD & control & CF026 & $\mathrm{f}$ & 2.292 & -15.7 \\
\hline Het & LD & control & CF83 & $\mathrm{m}$ & 2.189 & -13.4 & Het & LD & control & CF011 & $\mathrm{m}$ & 1.938 & -13 \\
\hline Het & LD & control & CF90 & $\mathrm{m}$ & 2.217 & -15.5 & Het & LD & control & CF014 & $\mathrm{m}$ & 2.196 & -15.9 \\
\hline Het & LD & control & CF92 & $\mathrm{m}$ & 1.671 & -13.9 & Het & LD & control & CF025 & $\mathrm{m}$ & 2.319 & -16 \\
\hline Het & LD & $6^{\circ} \mathrm{C}$ & CF66 & $\mathrm{f}$ & 1.971 & -21.2 & Het & LD & control & CF055 & $\mathrm{m}$ & 2.115 & -14.3 \\
\hline Het & LD & $6{ }^{\circ} \mathrm{C}$ & CF74 & $\mathrm{f}$ & 1.982 & -20.8 & Het & LD & $6{ }^{\circ} \mathrm{C}$ & CF006 & $\mathrm{f}$ & 2.378 & -13.9 \\
\hline Het & LD & $6^{\circ} \mathrm{C}$ & CF78 & $\mathrm{f}$ & 2.685 & -17.3 & Het & LD & $6^{\circ} \mathrm{C}$ & CF020 & $\mathrm{f}$ & 2.491 & -16.9 \\
\hline Het & LD & $6{ }^{\circ} \mathrm{C}$ & CF46 & $\mathrm{m}$ & 1.906 & -22 & Het & LD & $6^{\circ} \mathrm{C}$ & CF021 & $\mathrm{f}$ & 1.935 & -16.7 \\
\hline Het & LD & $6^{\circ} \mathrm{C}$ & CF69 & $\mathrm{m}$ & 2.4 & -18.1 & Het & LD & $6^{\circ} \mathrm{C}$ & CF030 & $\mathrm{f}$ & 2.085 & -17.2 \\
\hline Het & LD & $6{ }^{\circ} \mathrm{C}$ & CF72 & $\mathrm{m}$ & 2.033 & -17.9 & Het & LD & $6^{\circ} \mathrm{C}$ & CF034 & $\mathrm{f}$ & 2.933 & -15.5 \\
\hline Het & LD & $6^{\circ} \mathrm{C}$ & CF36 & $\mathrm{m}$ & 1.604 & -15.6 & Het & LD & $6^{\circ} \mathrm{C}$ & CF039 & $\mathrm{f}$ & 2.137 & -16.2 \\
\hline Het & LD & $6^{\circ} \mathrm{C}$ & CF64 & $\mathrm{f}$ & 2.18 & -16.7 & Het & LD & $6^{\circ} \mathrm{C}$ & CF003 & $\mathrm{m}$ & 1.622 & -16 \\
\hline Het & LD & $-2{ }^{\circ} \mathrm{C}$ & CF82 & $\mathrm{f}$ & 2.503 & -17.4 & Het & LD & $6{ }^{\circ} \mathrm{C}$ & CF033 & $\mathrm{m}$ & 2.262 & -16 \\
\hline Het & LD & $-2^{\circ} \mathrm{C}$ & CF86 & $\mathrm{f}$ & 2.846 & -17.9 & Het & LD & $-2{ }^{\circ} \mathrm{C}$ & CF040 & n.a. & n.a. & -13.6 \\
\hline Het & LD & $-2^{\circ} \mathrm{C}$ & CF87 & $\mathrm{f}$ & 2.479 & -17.9 & Het & LD & $-2{ }^{\circ} \mathrm{C}$ & CF043 & n.a. & n.a. & -14.3 \\
\hline Het & LD & $-2^{\circ} \mathrm{C}$ & CF88 & $\mathrm{f}$ & 2.428 & -21.2 & Het & LD & $-2^{\circ} \mathrm{C}$ & CF044 & n.a. & n.a. & -15 \\
\hline Het & LD & $-2^{\circ} \mathrm{C}$ & CF93 & $\mathrm{f}$ & 2.944 & -22.5 & Het & LD & $-2^{\circ} \mathrm{C}$ & CF052 & n.a. & n.a. & -17.6 \\
\hline Het & LD & $-2{ }^{\circ} \mathrm{C}$ & CF81 & $\mathrm{m}$ & 1.768 & -18.9 & Het & LD & $-2{ }^{\circ} \mathrm{C}$ & CF041 & n.a. & n.a. & -15.8 \\
\hline Het & LD & $-2{ }^{\circ} \mathrm{C}$ & CF31 & $\mathrm{f}$ & 1.91 & -15 & Het & LD & $-2{ }^{\circ} \mathrm{C}$ & CF045 & n.a. & n.a. & -15.7 \\
\hline $\mathrm{Hee}$ & SD & control & AT008 & $\mathrm{m}$ & 1.677 & -15.8 & Het & LD & $-2{ }^{\circ} \mathrm{C}$ & CF067 & n.a. & n.a. & -16.1 \\
\hline Hee & SD & control & AT010 & $\mathrm{m}$ & 1.612 & -19.2 & Hee & SD & control & AT32 & $\mathrm{m}$ & 1.819 & -17.6 \\
\hline Hee & SD & control & AT012 & $\mathrm{m}$ & 1.714 & -19.4 & $\mathrm{Hee}$ & SD & control & AT34 & $\mathrm{m}$ & 1.922 & -18.1 \\
\hline Hee & SD & control & AT024 & $\mathrm{f}$ & 2.203 & -22.7 & Hee & SD & control & AT36 & $\mathrm{m}$ & 1.73 & -15.7 \\
\hline $\mathrm{Hee}$ & SD & control & MS032 & $\mathrm{m}$ & 2.011 & -19.3 & $\mathrm{Hee}$ & SD & control & AT51 & $\mathrm{f}$ & 2.372 & -18.4 \\
\hline Hee & SD & control & MS036 & $\mathrm{f}$ & 1.874 & -11.1 & $\mathrm{Hee}$ & SD & control & AT52 & $\mathrm{f}$ & 1.8 & -16.6 \\
\hline Hee & SD & control & MS039 & $\mathrm{f}$ & 2.324 & -23.8 & Hee & SD & control & MS33 & $\mathrm{m}$ & 1.613 & -18.5 \\
\hline Hee & SD & control & AT025 & $\mathrm{f}$ & 1.756 & -19.8 & Hee & SD & control & MS43 & $\mathrm{f}$ & 2.173 & -11 \\
\hline $\mathrm{Hee}$ & SD & $6^{\circ} \mathrm{C}$ & AT016 & $\mathrm{f}$ & 2.134 & -20.6 & $\mathrm{Hee}$ & SD & control & MS46 & $\mathrm{f}$ & 1.933 & -18.1 \\
\hline $\mathrm{Hee}$ & SD & $6{ }^{\circ} \mathrm{C}$ & AT018 & $\mathrm{m}$ & 1.634 & -14.5 & Hee & SD & $6^{\circ} \mathrm{C}$ & VH003 & $\mathrm{m}$ & 1.633 & -15.5 \\
\hline Hee & SD & $6^{\circ} \mathrm{C}$ & AT022 & $\mathrm{m}$ & 1.948 & -20.6 & Hee & SD & $6^{\circ} \mathrm{C}$ & VH004 & $\mathrm{f}$ & 2.392 & -16.8 \\
\hline $\mathrm{Hee}$ & SD & $6{ }^{\circ} \mathrm{C}$ & MS005 & $\mathrm{m}$ & 2.374 & -20.5 & $\mathrm{Hee}$ & SD & $6^{\circ} \mathrm{C}$ & VH006 & $\mathrm{f}$ & 3.068 & -18.9 \\
\hline
\end{tabular}


Table A1. Cont.

\begin{tabular}{|c|c|c|c|c|c|c|c|c|c|c|c|c|c|}
\hline \multicolumn{7}{|c|}{ In-Vitro } & \multicolumn{7}{|c|}{ In-Vitro } \\
\hline Ecotype & Day Length & Treatment & ID Sample & Sex & Mass (g) & SCP & Ecotype & Day Length & Treatment & ID Sample & Sex & Mass (g) & SCP \\
\hline Hee & SD & $6{ }^{\circ} \mathrm{C}$ & MS010 & $\mathrm{f}$ & 2.432 & -17.9 & Hee & SD & $6^{\circ} \mathrm{C}$ & VH007 & $\mathrm{m}$ & 2.184 & -18.1 \\
\hline Hee & SD & $6^{\circ} \mathrm{C}$ & MS014 & $\mathrm{f}$ & 1.753 & -21.5 & $\mathrm{Hee}$ & SD & $6^{\circ} \mathrm{C}$ & VH013 & $\mathrm{m}$ & 2.015 & -18.4 \\
\hline Hee & SD & $6^{\circ} \mathrm{C}$ & AT017 & $\mathrm{f}$ & 2.197 & -19 & Hee & $\mathrm{SD}$ & $6^{\circ} \mathrm{C}$ & VH015 & $\mathrm{m}$ & 2.513 & -19.2 \\
\hline Hee & SD & $6{ }^{\circ} \mathrm{C}$ & AT023 & $\mathrm{m}$ & 1.711 & -19.8 & $\mathrm{Hee}$ & SD & $6^{\circ} \mathrm{C}$ & VH017 & $\mathrm{f}$ & 2.401 & -18.4 \\
\hline $\mathrm{Hee}$ & SD & $-2^{\circ} \mathrm{C}$ & AT028 & $\mathrm{m}$ & 2.396 & -18.2 & $\mathrm{Hee}$ & SD & $6^{\circ} \mathrm{C}$ & VH020 & $\mathrm{f}$ & 2.152 & -19.1 \\
\hline Hee & SD & $-2^{\circ} \mathrm{C}$ & AT029 & $\mathrm{m}$ & 1.985 & -17.2 & $\mathrm{Hee}$ & SD & $-2{ }^{\circ} \mathrm{C}$ & MS19 & $\mathrm{f}$ & 2.514 & -18.1 \\
\hline Hee & SD & $-2{ }^{\circ} \mathrm{C}$ & AT039 & $\mathrm{f}$ & 2.259 & -17.1 & Hee & SD & $-2{ }^{\circ} \mathrm{C}$ & VH021 & $\mathrm{m}$ & 2.366 & -18.7 \\
\hline Hee & SD & $-2{ }^{\circ} \mathrm{C}$ & MS007 & $\mathrm{m}$ & 2.189 & -20.2 & Hee & SD & $-2{ }^{\circ} \mathrm{C}$ & VH029 & $\mathrm{m}$ & 1.625 & -22.6 \\
\hline Hee & SD & $-2^{\circ} \mathrm{C}$ & MS015 & $\mathrm{f}$ & 2.499 & -17.2 & $\mathrm{Hee}$ & SD & $-2{ }^{\circ} \mathrm{C}$ & VH030 & $\mathrm{m}$ & 1.992 & -22.8 \\
\hline Hee & SD & $-2^{\circ} \mathrm{C}$ & MS016 & $\mathrm{f}$ & 2.472 & -17.4 & $\mathrm{Hee}$ & SD & $-2{ }^{\circ} \mathrm{C}$ & VH035 & $\mathrm{f}$ & 2.559 & -20.1 \\
\hline Hee & SD & $-2^{\circ} \mathrm{C}$ & AT042 & $\mathrm{f}$ & 1.968 & -15.3 & Hee & SD & $-2^{\circ} \mathrm{C}$ & VH036 & $\mathrm{m}$ & 2.611 & -22.2 \\
\hline Het & SD & control & Mad143 & $\mathrm{f}$ & 2.599 & -18.8 & $\mathrm{Hee}$ & SD & $-2{ }^{\circ} \mathrm{C}$ & VH039 & $\mathrm{f}$ & 2.033 & -18.4 \\
\hline Het & SD & control & Mad073 & $\mathrm{f}$ & 3.08 & -19.2 & Het & SD & control & CF099 & $\mathrm{f}$ & 1.912 & -16.6 \\
\hline Het & SD & control & Mad029 & $\mathrm{m}$ & 2.549 & -17.3 & Het & SD & control & CF103 & $\mathrm{f}$ & 1.626 & -17.1 \\
\hline Het & SD & control & Mad003 & $\mathrm{m}$ & 2.704 & -16.8 & Het & SD & control & CF037 & $\mathrm{m}$ & 1.956 & -15.2 \\
\hline Het & SD & control & Mad072 & $\mathrm{f}$ & 2.452 & -20.1 & Het & SD & control & CF077 & $\mathrm{m}$ & 2.195 & -17.6 \\
\hline Het & SD & control & Mad074 & $\mathrm{m}$ & 2.224 & -19 & Het & SD & control & CF009 & $\mathrm{f}$ & 2.061 & -19.2 \\
\hline Het & SD & control & Mad001 & $\mathrm{m}$ & 2.186 & -20.2 & Het & SD & control & CF013 & $\mathrm{m}$ & 1.232 & -17.9 \\
\hline Het & SD & $6^{\circ} \mathrm{C}$ & CF024 & $\mathrm{f}$ & 2.148 & -19.6 & Het & SD & control & CF018 & $\mathrm{f}$ & 1.791 & -17.5 \\
\hline Het & SD & $6^{\circ} \mathrm{C}$ & CF028 & $\mathrm{f}$ & 2.1 & -20.9 & Het & SD & $6^{\circ} \mathrm{C}$ & CF017 & $\mathrm{f}$ & 2.397 & -16.7 \\
\hline Het & SD & $6^{\circ} \mathrm{C}$ & CF029 & $\mathrm{f}$ & 2.265 & -19.9 & Het & $\mathrm{SD}$ & $6^{\circ} \mathrm{C}$ & CF019 & $\mathrm{f}$ & 1.853 & -17.5 \\
\hline Het & SD & $6^{\circ} \mathrm{C}$ & CF023 & $\mathrm{m}$ & 1.646 & -22.3 & Het & SD & $6^{\circ} \mathrm{C}$ & CF020 & $\mathrm{f}$ & 2.166 & -14.2 \\
\hline Het & SD & $6{ }^{\circ} \mathrm{C}$ & CF027 & $\mathrm{m}$ & 2.207 & -16.1 & Het & SD & $6^{\circ} \mathrm{C}$ & CF022 & $\mathrm{f}$ & 2.03 & -19.1 \\
\hline Het & SD & $6{ }^{\circ} \mathrm{C}$ & CF030 & $\mathrm{m}$ & 2.207 & -16.3 & Het & SD & $6^{\circ} \mathrm{C}$ & CF001 & $\mathrm{m}$ & 2.107 & -16.5 \\
\hline Het & SD & $6^{\circ} \mathrm{C}$ & CF033 & $\mathrm{f}$ & 2.036 & -17.8 & Het & SD & $6^{\circ} \mathrm{C}$ & CF005 & $\mathrm{m}$ & 2.333 & -16.3 \\
\hline Het & SD & $6^{\circ} \mathrm{C}$ & CF016 & $\mathrm{m}$ & 2.182 & -21.1 & Het & $\mathrm{SD}$ & $6{ }^{\circ} \mathrm{C}$ & CF010 & $\mathrm{m}$ & 2.216 & -16.9 \\
\hline Het & SD & $-2^{\circ} \mathrm{C}$ & CF097 & $\mathrm{f}$ & 2.696 & -17.8 & Het & SD & $6{ }^{\circ} \mathrm{C}$ & CF013 & $\mathrm{m}$ & 1.847 & -16.9 \\
\hline Het & SD & $-2^{\circ} \mathrm{C}$ & CF098 & $\mathrm{f}$ & 2.286 & -22.9 & Het & SD & $-2{ }^{\circ} \mathrm{C}$ & CF041 & $\mathrm{f}$ & 2.762 & -20.7 \\
\hline Het & SD & $-2^{\circ} \mathrm{C}$ & CF101 & $\mathrm{f}$ & 2.217 & -16.5 & Het & SD & $-2{ }^{\circ} \mathrm{C}$ & CF053 & $\mathrm{f}$ & 2.575 & -18.7 \\
\hline Het & SD & $-2{ }^{\circ} \mathrm{C}$ & CF102 & $\mathrm{f}$ & 2.21 & -19.9 & Het & SD & $-2^{\circ} \mathrm{C}$ & CF057 & $\mathrm{f}$ & 2.532 & -16.7 \\
\hline
\end{tabular}


Table A1. Cont.

\begin{tabular}{|c|c|c|c|c|c|c|c|c|c|c|c|c|c|}
\hline \multicolumn{7}{|c|}{ In-Vitro } & \multicolumn{7}{|c|}{ In-Vitro } \\
\hline Ecotype & Day Length & Treatment & ID Sample & Sex & Mass (g) & SCP & Ecotype & Day Length & Treatment & ID Sample & Sex & Mass (g) & SCP \\
\hline Het & SD & $-2{ }^{\circ} \mathrm{C}$ & CF064 & $\mathrm{m}$ & 2.253 & -20.8 & Het & SD & $-2{ }^{\circ} \mathrm{C}$ & CF075 & $\mathrm{f}$ & 2.338 & -16.4 \\
\hline Het & SD & $-2{ }^{\circ} \mathrm{C}$ & CF070 & $\mathrm{m}$ & 2.287 & -18.2 & Het & SD & $-2{ }^{\circ} \mathrm{C}$ & CF093 & $\mathrm{m}$ & 1.755 & -18.6 \\
\hline Het & SD & $-2^{\circ} \mathrm{C}$ & CF104 & $\mathrm{m}$ & 1.814 & -18.5 & Het & SD & $-2{ }^{\circ} \mathrm{C}$ & CF039 & $\mathrm{m}$ & 1.91 & -11.3 \\
\hline Het & SD & $-2{ }^{\circ} \mathrm{C}$ & CF069 & $\mathrm{m}$ & 1.636 & -23.7 & Het & SD & $-2{ }^{\circ} \mathrm{C}$ & CF051 & $\mathrm{m}$ & 2.389 & -16.6 \\
\hline Hee & SD & long term & MS31 & $\mathrm{f}$ & 2.273 & -19.5 & Het & SD & $-2{ }^{\circ} \mathrm{C}$ & CF096 & $\mathrm{m}$ & 2.019 & -16.1 \\
\hline Hee & SD & long term & AT53 & $\mathrm{f}$ & 2.267 & -20.7 & $\mathrm{Hee}$ & SD & long term & MS25 & $\mathrm{f}$ & 2.228 & -17.4 \\
\hline Hee & SD & long term & AT58 & $\mathrm{f}$ & 2.467 & -22.4 & Hee & SD & long term & MS26 & $\mathrm{f}$ & 1.781 & -17 \\
\hline Hee & SD & long term & AT47 & $\mathrm{f}$ & 1.838 & -23.6 & Hee & SD & long term & MS28 & $\mathrm{f}$ & 2.237 & -17.1 \\
\hline Hee & SD & long term & AT59 & $\mathrm{m}$ & 1.793 & -21.3 & Hee & SD & long term & AT30 & $\mathrm{f}$ & 2.002 & -20.4 \\
\hline $\mathrm{Hee}$ & SD & long term & AT60 & $\mathrm{m}$ & 1.641 & -20.8 & $\mathrm{Hee}$ & SD & long term & MS24 & $\mathrm{f}$ & 2.571 & -19.1 \\
\hline Hee & SD & long term & MS11 & $\mathrm{m}$ & 2.204 & -22.1 & Hee & SD & long term & MS48 & $\mathrm{m}$ & 1.539 & -16.6 \\
\hline Hee & SD & long term & MS30 & $\mathrm{f}$ & 1.75 & -17.6 & Hee & SD & long term & AT31 & $\mathrm{m}$ & 1.618 & -17.6 \\
\hline Het & SD & long term & Mad077 & $\mathrm{f}$ & 2.757 & -22.6 & Hee & SD & long term & AT43 & $\mathrm{m}$ & 1.766 & -21.6 \\
\hline Het & SD & long term & Mad060 & $\mathrm{f}$ & 2.144 & -16.6 & Het & SD & long term & Mad082 & $\mathrm{f}$ & 2.328 & -14.3 \\
\hline Het & SD & long term & Mad103 & $\mathrm{f}$ & 2.972 & -24.3 & Het & $\mathrm{SD}$ & long term & Mad059 & $\mathrm{f}$ & 2.408 & -11.8 \\
\hline Het & SD & long term & Mad114 & $\mathrm{m}$ & 1.922 & -17.7 & Het & SD & long term & Mad098 & $\mathrm{f}$ & 3.154 & -15.9 \\
\hline Het & SD & long term & Mad079 & $\mathrm{m}$ & 2.399 & -21.4 & Het & SD & long term & Mad030 & $\mathrm{m}$ & 2.653 & -14.2 \\
\hline \multirow[t]{2}{*}{ Het } & SD & long term & Mad087 & $\mathrm{m}$ & 2.082 & -19.7 & Het & SD & long term & Mad126 & $\mathrm{m}$ & 2.113 & -12.7 \\
\hline & & & & & & & Het & SD & long term & Mad041 & $\mathrm{m}$ & 2.773 & -16.9 \\
\hline
\end{tabular}




\section{References}

1. Mende, M.B.; Bartel, M.; Hundsdoerfer, A.K. A comprehensive phylogeography of the Hyles euphorbiae complex (Lepidoptera: Sphingidae) indicates a "glacial refuge belt". Sci. Rep. 2016, 6, 29527. [CrossRef]

2. Hundsdoerfer, A.K.; Lee, K.M.; Kitching, I.J.; Mutanen, M. Genome-wide SNP Data Reveal an Overestimation of Species Diversity in a Group of Hawkmoths. Genome Biol. Evol. 2019, 11, 136-2150. [CrossRef] [PubMed]

3. Hundsdoerfer, A.K.; Kitching, I.J.; Wink, M. A molecular phylogeny of the hawkmoth genus Hyles (Lepidoptera: Sphingidae, Macroglossinae). Mol. Phyl. Evol. 2005, 35, 442-458. [CrossRef] [PubMed]

4. Hundsdoerfer, A.K.; Rubinoff, D.; Attié, M.; Wink, M.; Kitching, I.J. A revised molecular phylogeny of the globally distributed hawkmoth genus Hyles (Lepidoptera: Sphingidae), based on mitochondrial and nuclear DNA sequences. Mol. Phyl. Evol. 2009, 52, 852-865. [CrossRef]

5. Hundsdoerfer, A.K.; Mende, M.B.; Harbich, H.; Pittaway, A.R.; Kitching, I.J. Larval pattern morphotypes in the Western Palaearctic Hyles euphorbiae complex (Lepidoptera: Sphingidae: Macroglossinae). Insect Syst. Evol. 2011, 42, 41-86.

6. Hundsdoerfer, A.K.; Mende, M.B.; Kitching, I.J.; Cordellier, M. Taxonomy, phylogeography and climate relations of the Western Palaearctic spurge hawkmoth (Lepidoptera, Sphingidae, Macroglossinae). Zool. Scr. 2011, 40, 403-417. [CrossRef]

7. Mende, M.B.; Hundsdoerfer, A.K. Mitochondrial lineage sorting in action-Historical biogeography of the Hyles euphorbiae complex (Sphingidae, Lepidoptera) in Italy. BMC Evol. Biol. 2013, 13, 83. [CrossRef]

8. Ayres, M.P.; Scriber, J.M. Local adaptation to regional climates in Papilio canadensis (Lepidoptera: Papilionidae). Ecol. Monogr. 1994, 64, 465-482. [CrossRef]

9. Aardema, M.; Scriber, J.; Hellmann, J. Considering local adaptation in issues of lepidopteran conservation-A review and recommendations. Am. Midl. Nat. 2011, 165, 294-303. [CrossRef]

10. Barth, M.B.; Buchwalder, K.; Kawahara, A.Y.; Zhou, X.; Liu, S.; Krezdorn, N.; Rotter, B.; Horres, R.; Hundsdoerfer, A.K. Functional characterization of the Hyles euphorbiae hawkmoth transcriptome reveals strong expression of phorbol ester detoxification and seasonal cold hardiness genes. Front. Zool. 2018, 15, 20. [CrossRef]

11. Stuckas, H.; Mende, M.B.; Hundsdoerfer, A.K. Response to cold acclimation in diapause pupae of Hyles euphorbiae (Lepidoptera: Sphingidae): Candidate biomarker identification using proteomics. Insect Mol. Biol. 2014, 23, 444-456. [CrossRef] [PubMed]

12. Harbich, H. Das photosensible Raupenstadium von Celerio euphorbiae euphorbiae (Lep.: Sphingidae). Entomol. Z. 1976, 86, 233-236.

13. World Weather \& Climate Information. Available online: https:/ / weather-and-climate.com/ (accessed on 23 March 2020).

14. De Freina, J. Über Biologie, Morphologie und Taxonomie von Hyles tithymali deserticola (Bartel). Entomol. Z. 1994, 104, 33-60.

15. Harris, P.; Alex, J. Euphorbia esula L., leafy spurge, and Euphorbia cyparissias L., cypress spurge (Euphorbiaceae). Commonw. Inst. Biol. Contr. Tech. Commun. 1971, 4, 83-88.

16. Heller, J.; Mochnacka, I. Hyperglycaemic reaction in overwintering pupae. Compt. Rend. Soc. Sci. Let Wroc. 1951, 6, 56-57.

17. Pittaway, A.R. HYLES Hübner, [1819]. Available online: https://tpittaway.tripod.com/sphinx/h_eup.htm (accessed on 15 March 2020).

18. Zachariasson, K.E. Physiology of cold tolerance in insects. Physiol. Rev. 1985, 65, 799-832. [CrossRef]

19. Kukal, O.; Serianni, A.S.; Duman, J.G. Glycerol metabolism in a freeze-tolerant arctic insect: An in vivo ${ }^{13}$ C NMR study. J. Comp. Physiol. B 1988, 158, 175-183. [CrossRef]

20. Khani, A.; Moharramipour, S.; Barzegar, M.; Naderi-Manesh, H. Comparison of fatty acid composition in total lipid of diapause and non-diapause larvae of Cydia pomonella (Lepidoptera: Tortricidae). Insect Sci. 2007, 14, 125-131. [CrossRef]

21. Denlinger, D.L. Regulation of diapause. Ann. Rev. Entomol. 2002, 47, 93-122. [CrossRef]

22. Bale, J.S. Insect cold hardiness: A matter of life and death. Eur. J. Entomol. 1996, 93, 369-382.

23. Lee, R.E.; Costanzo, J.P.; Mugano, J.A. Regulation of supercooling and ice nucleation in insects. Eur. J. Entomol. 1996, 93, 405-418.

24. Vanin, S.; Bubacco, L.; Beltramini, M. Seasonal variation of trehalose and glycerol concentrations in winter snow-active insects. CryoLetters 2008, 29, 485-491. [PubMed]

25. Wharton, D.A. Supercooling and freezing tolerant animals. In Supercooling; Wilson, P., Ed.; InTech: Rijeka, Croatia, 2012; pp. 17-28.

26. De Freina, J.J. Über Biologie und Morphologie der auf Madeira beheimateten Hyles euphorbiae gecki ssp.n. (Lepidoptera, Sphingidae). Nachr. Bayer Entomol. 1991, 40, 65-72.

27. Bachmetjev, P.T. Experimentelle entomologische Studien, Band I; Facsimile Publisher: Leipzig, Germany, 1901; 160p.

28. Wittstadt, H. Wanderfalterbericht für das Jahr 1965. Entomol. Z. 1966, 76, 241-243.

29. Harbich, H. Erfahrungen bei der Aufzucht von Sphingidenraupen mit einem Kombinationsfutter (Lepidoptera: Sphingidae). Entomol. Z. 1994, 104, 112-117.

30. Block, W. Cold tolerance of insects and other arthropods. Trans. R. Soc. Lond. B Biol. Sci. 1990, 326, 613-633.

31. Deswal, R.; Sharma, B. Antifreeze proteins in plants: An overview with an insight into the detection techniques including nanobiotechnology. J. Prot. Proteom. 2014, 5, 89-107.

32. Carrillo, M.A.; Kaliyan, N.; Cannon, C.A.; Morey, R.V.; Wilcke, W.F. A simple method to adjust cooling rates for supercooling point determination. CryoLetters 2004, 25, 155-160. 
33. Carrillo, M.A.; Cannon, C.A.; Wilcke, W.F.; Morey, R.V.; Kaliyan, N.; Hutchison, W.D. Relationship between supercooling point and mortality at low temperatures in Indian meal moth (Lepidoptera: Pyralidae). J. Econ. Entomol. 2005, 98, 618-625. [CrossRef]

34. StatSoft Inc. STATISTICA (Data Analysis Software System), Version 8.0. Available online: www.statsoft.com (accessed on 14 February 2008).

35. Khani, A.; Moharramipour, S. Cold hardiness and supercooling capacity in the overwintering larvae of the codling moth. Cydia pomonella. J. Insect Sci. 2010, 10, 83.

36. Sinclair, B.J.; Addo-Bediako, A.; Chown, S.L. Climatic variability and the evolution of insect freeze tolerance. Biol. Rev. 2003, 78, 181-195. [CrossRef]

37. Bale, J.S.; Hayward, S.A.L. Insect overwintering in a changing climate. J. Exp. Biol. 2010, 213, 980-994. [CrossRef] [PubMed]

38. Teets, N.M.; Denlinger, D.L. Physiological mechanisms of seasonal and rapid cold-hardening in insects. Physiolog. Entomol. 2013, 38, 105-116. [CrossRef]

39. Duman, J.G. Animal ice binding (antifreeze) proteins and glycolipids: An overview with emphasis on physiological function. J. Exp. Biol. 2015, 218, 1846-1855. [CrossRef] [PubMed]

40. Carrillo, M.A.; Cannon, C.A. Supercooling point variability in the Indian meal moth, Plodia interpunctella (Hübner) (Lepidoptera: Pyralidae). J. Stor. Prod. Res. 2005, 41, 556-564. [CrossRef]

41. Khani, A.; Moharramipour, S. Seasonal change of cold hardiness in the codling moth, Cydia pomonella (Lepidoptera: Tortricidae). Pak. J. Biol. Sci. 2007, 10, 2591-2594. [CrossRef] [PubMed]

42. Sømme, L. The physiology of cold hardiness in terrestrial arthropods. Eur. J. Entomol. 1999, 96, 1-10.

43. Sinclair, B.J. Insect cold tolerance: How many kinds of frozen? Eur. J. Entomol. 1999, 96, 157-164.

44. Sinclair, B.J.; Vernon, P.; Klok, C.J.; Chown, S.L. Insects at low temperatures: An ecological perspective. Tr. Ecol. Evol. 2003, 18, 257-262. [CrossRef]

45. Turnock, W.J.; Fields, P.G. Winter climates and cold hardiness in terrestrial insects. Eur. J. Entomol. 2005, 102, 561. [CrossRef]

46. Goto, S.G.; Numata, H. Insect photoperiodism. In Insect Molecular Biology and Ecology; Hoffmann, K.H., Ed.; CRC Press: Boca Raton, FL, USA, 2014; pp. 217-244.

47. Pullin, A.S. Physiological relationships between insect diapause and cold tolerance: Coevolution or coincidence. Eur. J. Entomol. 1996, 93, 121-130.

48. Nylin, S. Induction of diapause and seasonal morphs in butterflies and other insects: Knowns, unknowns and the challenge of integration. Physiol. Entomol. 2013, 38, 96-104. [CrossRef]

49. Storey, K.B.; Storey, J.M. Insect cold hardiness: Metabolic, gene, and protein adaptation. Can. J. Zool. 2012, 90, 456-475. [CrossRef]

50. Denlinger, D.L. Relationship between cold hardiness and diapause. In Insects at Low Temperatures; Lee, R.E., Denlinger, D.L., Eds.; Chapman and Hall: New York, NY, USA, 1991; pp. 174-198.

51. Hahn, D.A.; Denlinger, D.L. Energetics of insect Diapause. Annu. Rev. Entomol. 2011, 56, 103-121. [CrossRef] [PubMed]

52. Atapour, M.; Moharramipour, S. Changes of cold hardiness, supercooling capacity, and major cryoprotectants in overwintering larvae of Chilo suppressalis (Lepidoptera: Pyralidae). Environ. Entomol. 2009, 38, 260-265. [CrossRef]

53. Soudi, S.H.; Moharramipour, S. Cold tolerance and supercooling capacity in overwintering adults of elm leaf beetle Xanthogaleruca luteola (Coleoptera: Chrysomelidae). Environ. Entomol. 2011, 40, 1546-1553. [CrossRef]

54. Bemani, M.; Izadi, H.; Mahdian, K.; Khani, A. Study on the physiology of diapause, cold hardiness and supercooling point of overwintering pupae of the pistachio fruit hull borer, Arimania comaroffi. J. Insect Physiol. 2012, 58, 897-902. [CrossRef]

55. Williams, C.M.; Nicolai, A.; Ferguson, L.V.; Bernards, M.A.; Hellmann, J.J.; Sinclair, B.J. Cold hardiness and deacclimation of overwintering Papilio zelicaon pupae. Comp. Biochem. Physiol. A Mol. Int. Physiol. 2014, 178, 51-58. [CrossRef] [PubMed]

56. Eizaguirre, M.; López, C.; Asín, L.; Albajes, R. Thermoperiodism, photoperiodism and sensitive stage in the diapause induction of Sesamia nonagrioides (Lepidoptera: Noctuidae). J. Insect Physiol. 1994, 40, 113-119. [CrossRef]

57. Gomi, T. Geographic variation in critical photoperiod for diapause induction and its temperature dependence in Hyphantria cunea Drury (Lepidoptera: Arctiidae). Oecologia 1997, 111, 160-165. [CrossRef]

58. Gill, H.M.; Goyal, G.; Chahil, G. Insect Diapause: A Review. J. Agric. Sci. Technol. 2017, 7, 454-473.

59. Wang, X.P.; Yang, Q.S.; Dalin, P.; Zhou, X.M.; Luo, Z.W.; Lei, C.L. Geographic variation in photoperiodic diapause induction and diapause intensity in Sericinus montelus (Lepidoptera: Papilionidae). Insect Sci. 2012, 19, 295-302. [CrossRef]

60. Chen, Y.S.; Chen, C.; He, H.M.; Xia, Q.W.; Xue, F.S. Geographic variation in diapause induction and termination of the cotton bollworm, Helicoverpa armigera Hübner (Lepidoptera: Noctuidae). J. Insect Physiol. 2013, 59, 855-862. [CrossRef] [PubMed]

61. Ryan, S.F.; Valella, P.; Thivierge, G.; Aardema, M.L.; Scriber, J.M. The role of latitudinal, genetic and temperature variation in the induction of diapause of Papilio glaucus (Lepidoptera: Papilionidae). Insect Sci. 2018, 25, 328-336. [CrossRef] [PubMed]

62. Xiao, H.J.; Mou, F.C.; Zhu, X.F.; Xue, F.S. Diapause induction, maintenance and termination in the rice stem borer Chilo suppressalis (Walker). J. Insect Physiol. 2010, 56, 1558-1564. [CrossRef] [PubMed]

63. Klockmann, M.; Fischer, K. Strong reduction in diapause survival under warm and humid overwintering conditions in a temperate-zone butterfly. Popul. Ecol. 2019, 61, 150-159. [CrossRef]

64. Pittaway, A.R. The Hawkmoths of the Western Palaearctic; Harley Books: Colchester, UK, 1993; p. 240. 